\title{
3 \\ Moral Risk in a Nursing Home
}

"One fine summer day, a local fisher came to the nursing home door with buckets full of fresh fish that he had just caught from his boat. He wanted to give it to us free of charge. We rejoiced, and thought that now we could create a fish barbecue for the residents. They would be so happy to get fresh food straight from the sea on their plates. The air at the nursing home would be filled with the pleasant smell of grilled fish. Then one of us remembered what the law says about food at the nursing home. Everything we serve as food to the residents has to come from a registered supplier, and the fisher was not on the list. This meant that it would be illegal to grill and serve the fresh fish from the sea at the home. Still we felt that it would be the right thing to do, as it would be such a rich and thrilling experience for the residents" (Norlin \& Borvik, 2016).

This event took place at Søbakken, a nursing home in the coastal town of Helgeroa in Norway. A change in leadership there in 2011 brought about swift improvement in the work environment and in the living conditions for the residents. Søbakken had a bad reputation in the local community, both as a place to work and as a place to live. That changed rapidly when nurse Kristine Borvik took over as the leader of the nursing home, with nurse Helén Norlin as the assistant 
leader. The development at Søbakken has come under scrutiny in a research project, based on data from interviews with employees, residents, relatives, and other people from the local community (Carlsen \& Kvalnes, 2015). This chapter builds on further interviews with Borvik and Norlin, to unveil details in narratives concerning moral risk and fallibility at Søbakken. Their initiatives are studied through the lens of a distinction between active and passive mistakes, or between doing something you should not have done, and refraining from doing something you should have done. The activities they generated at the nursing home increased the likelihood of committing active mistakes, and reduced the likelihood of committing passive mistakes.

This chapter addresses three principled questions regarding responsibility and risk at work: (1) To what extent do our moral evaluations of past decisions and behavior depend on actual outcomes? The concept of moral luck (Nagel, 1979; Williams, 1981) captures the paradoxical phenomenon that the way things actually turn out affect verdicts of the right or wrongness of what people do, even though we take morality to be a dimension of behavior where it is only reasonable to hold people responsible for what has been within their control. (2) What kind of protection against sanctions should be in place for people who take risky decisions at work? Moral hazard occurs in situations where people choose high-risk options because they feel insulated against taking the burden if things should end badly. A less acknowledged phenomenon is what we may call moral paralysis, where people become passive because they feel that they will have to take the burden alone if things should end badly. Moral hazard can lead to an overload of active mistakes, while moral paralysis can encourage passive mistakes. (3) What is the role of leaders in cases where either active or passive mistakes from employees lead to bad outcomes? The Søbakken activities did not lead to serious harm to residents, but might have done so, and that would have been at the test of the extent to which their closest local council leader would have stood by or distanced herself from the nursing home leaders.

The narratives in this chapter are mainly from a nursing home, but the discussion points to theoretical and practical implications beyond that field of work, with regard to how organizations (1) cope with moral 
luck, (2) strike a balance between moral hazard and moral paralysis, and to how (3) leaders provide support to exposed and vulnerable employees in critical situations.

\section{$1 \quad$ Active and Passive Mistakes}

Crucial to the positive development at Søbakken was an initiative from the new leaders to involve employees and residents in reflections about how they wanted life to be there. The nurses started by asking them a very fundamental set of questions: What do you want? What is a good life for you here? (Carlsen \& Kvalnes, 2015) In a reflection note, Borvik and Norlin write: "We have experienced that it is smart to dig some more when we ask our residents, and not be satisfied with "everything is OK, or I don't know ...". We ask them what they used to do earlier in life when they were younger. What did you enjoy during the summer, when you were younger? If they cannot answer themselves, we ask a relative" (Norlin \& Borvik, 2015).

The answers from the residents exposed misunderstandings about daily routines and preferences, but also a much more fundamental desire. The old people who lived at Søbakken wanted to have more contact with life. Currently, they felt separated from meaningful activity, stored away from the rest of the community, out of sight, to wither and die. Many of the projects and initiatives at Søbakken in the months and years to follow attempted to bring the residents closer to the life outside the walls of the nursing home, both by inviting people outsiders of all ages in, and by taking the residents on trips. Activities like sightseeing bus tours, beer brewing, mini-concerts, exercise sessions, bazaars, boat trips, public reading sessions, Christmas tree lighting, visits from the local school band, and bathing trips to the sea, contributed to bringing the residents closer to life. The residents came more in touch with the community in which they had grown up and lived earlier (Carlsen \& Kvalnes, 2015).

Autonomy and social functioning are important to human well-being at all stages of life, including old age (Bangerter, Heid, Abbott, \& Van Haitsma, 2016; Paque, Goossens, Elseviers, Van Bogaert, \& Dilles, 2016). 
Bringing an old person out of his or her isolation at a nursing home and in tighter contact with life is in itself a commendable initiative, but will sometimes involve a raised risk of personal harm to that person. Moral risk is the kind of risk that exposes the decision-maker to moral criticism and blame, based on whether things go well or not. If the outcome is fine, the instigators are likely to receive praise, while if something goes wrong and the old person is harmed in some way, they can become subject to criticism and blame, and more formally to legal repercussions. One basic challenge for the leaders at Søbakken was that in order to meet the residents' desire to come closer to life again, they also on some occasions had to increase the risk of harm, and thus expose themselves to moral risk. Going on a bus trip to the sea with fragile, old people involves more risk that something will go wrong than keeping them in the sofa back at the nursing home. One fragile old woman expressed an eager desire to swim in the sea, an activity she had loved earlier in life, but there was no way of telling in advance how her body would respond when it was brought into the rather cold sea water. The trip from the nursing home to the sea was also one where small accidents could affect her badly. Movement and activity are good in itself, but will be seen in a different light by relatives, authorities, and the media if someone ends up with a heart failure, a concussion or a broken hip bone. The woman did get her desire fulfilled, and had a wonderful experience in the water, but taking her there was a risky endeavor.

We can apply a distinction between active and passive mistakes in order to conceptualize the change in moral orientation at Søbakken. You make an active mistake if you do something that you should not have done, and a passive mistake if you refrain from doing something that you should have done. In many work settings, the balance and priority between active or passive mistakes can make a considerable difference to practice. In surgery, the doctors can face situations of doubt about whether a patient suffers from appendicitis or not, and must decide to operate or not. Operating on a person who does not in fact have appendicitis will constitute an active mistake, doing something one should not have done, while sending a person with appendicitis home without surgery will be a passive mistake, refraining from doing something one should actually have done. During a year, the team of 
doctors may face a number of doubt cases, and they are likely to make mistakes. They can make a conscious choice about what kind of mistake they are prepared to tolerate the most, either operating on someone who in fact does not need it, thus creating unnecessary complications and exposure to harm to that person, or failing to operate on someone who actually needs it, and prolonging the suffering for that person.

In a finance setting, the difference between active and passive mistakes can occur with regard to evaluations of which customers should and should not get a particular kind of loan. Even here, we can imagine a set of doubtful cases, where it is uncertain whether customers are capable of handling the loan for which they have applied. It can be an active mistake to provide a loan to someone who will not be able to repay it and will have his or her economy put in jeopardy because of it. It will be a passive mistake to refuse a loan to someone who would be able to handle it well, and may now not be able to pursue a particular project, due to a lack of funding. Even in the bank context, a decision can be made regarding a higher or lower tolerance for active and passive mistakes.

In a nursing home, an active mistake can be to initiate some specific activity that leads to harm to one or more residents, while a passive mistake can be to refrain from doing something that would have been good and beneficial for them. The development at Søbakken involved a move towards taking risks that might end up as active mistakes, since they might have harmful outcomes. The established routines that the residents complained about, being stored away and separated from life, seemed designed to avoid active mistakes, with the unacknowledged consequence of making passive mistakes of not giving them sufficient exercise and movement, and distancing them from the local community.

The practice of pacifying residents in a nursing home can be seen as a result of omission bias, or the assumption that harmful outcomes of actions (active mistakes) are more serious and important to avoid than harmful outcomes of omissions (passive mistakes) (Asch et al., 1994; Baron \& Ritov, 2004; Ritov \& Baron, 1990; Spranca, Minsk, \& Baron, 1991). Omission bias indicates a more or less conscious preference for harm caused by omissions over equal or lesser harm caused by acts. Omission bias can affect vaccination decisions, in that many people 
consider the risk of harm from vaccination as more serious than the risk from omitting vaccination (Ritov \& Baron, 1990). There is a link here to attitudes towards risky play, discussed in chapter one. Harms that might occur when children climb trees or roam their neighborhood can be considered as more serious than the less tangible harms caused by shutting them off from those activities. Childhood research tells us that passivity in children can have a bad impact on their mental and physical development, but for a concerned and anxious parent, that consequence can appear to be more acceptable than the harm that can result from risky play (Sandseter \& Kennair, 2011). Applied to a nursing home environment, omission bias can mean that harm caused by initiatives to activate residents are seen as more serious than harms from leaving residents with limited scope of action in their beds or rooms.

Omission bias can be placed in the context of a tendency to formulate ethics in proscriptive terms (this is what we should not do), with an emphasis on avoiding harm, and not in prescriptive terms (this is what we should do), where the aim is to advance positive outcomes (Carnes \& Janoff-Bulman, 2012). This line of thinking builds on Kant's distinction between negative and positive moral duty, between the moral duty to do no harm, and the moral duty to do good for others. A proscriptive ethics has low tolerance for active mistakes and a higher tolerance for passive mistakes, and vice versa for a prescriptive ethics, The activities at Søbakken that came as responses to the residents' wish to come closer to life indicate a prescriptive ethics, since the main motivation was to make positive differences in the lives of elderly people. Initiatives did raise the probability that active mistakes would occur, but lowered the probability of passive mistakes. The previous regime at the nursing home seems to have advocated a proscriptive ethics, with emphasis on safety and avoiding injury, and that appears to be the norm in the nursing of elderly people in Norway.

The commitment to bring residents closer to life, even at the expense of increased risk of harm, raises principled questions about the tolerance for active and passive mistakes. The next section returns to the opening narrative of whether to arrange a fish barbecue for the residents at Søbakken. The concept of moral luck can be useful in shedding light 
on the issues that are at stake in that situation, since it emphasizes how actual outcomes color the moral judgements we tend to make.

\section{The Fish Dilemma}

The local fisher had noticed the positive development at Søbakken, and wanted to contribute in his own way. That is why he turned up one morning with buckets full of fresh fish. The leaders at the nursing home wanted to make a barbecue for the residents, but realized that the law forbids them to do so. Fish should come frozen or vacuum packed from a registered supplier that would guarantee its quality and safety. That legal requirement makes sense from the perspective of food safety and protecting the residents from harm. Fish can be contaminated or contain hazardous bones, and so pose a threat to the health of those who eat it. From a proscriptive standpoint, then, one should not serve fish from a local fisher, no matter how tempting that might be. On the other hand, from a prescriptive standpoint, one should try to enrich people's lives when there is an opportunity to do so. A barbecue with fresh fish would be a thrilling and memorable event for the residents at Søbakken, one they would know to appreciate in full.

A decision to break the law and serve the fresh fish could be seen as an instance of civil disobedience, a situation where otherwise lawabiding citizens give priority to moral considerations over legal ones, because they think the law is unreasonable. A justification of this kind can be interpreted to belong at the sixth stage of moral development, identified in Kohlberg's theory of moral development (Kohlberg, 1973). On this stage, decisions are based on the application of universal ethical principles that are considered to be above local law and legislation. It is a stage where the Golden Rule and related principles like Kant's categorical imperative dominate. Interviews with the leaders at Søbakken indicate that the principled question they asked themselves in times of doubt was whether they would have accepted that their own parents were subject to the decisions under consideration. Putting yourself in the shoes of those affected by your own decision is a typical ingredient of principled moral reasoning. In the fish dilemma, the leaders at 
Søbakken reasoned about whether they would have accepted that the nursing home where their own parents stayed, arranged a grill party where they illegally served fresh fish from an unregistered supplier.

The fact that someone's moral reasoning follows the pattern described by Kohlberg as belonging to the highest and most mature form of moral development is no indication that the decision is correct. Lunatics can reason in ways that perfectly follow the procedure drawn up in the maxims of Kant's categorical imperative. We can distinguish between the form and content of moral reasoning, and suffice to say here is that considering to set the law aside and prioritizing one's own moral convictions has the form of Kohlberg's sixth stage moral reasoning.

Opposition to the principled line of thinking at Kohlberg's highest stage could come from someone on the fifth stage, where the emphasis is placed on social contracts and decisions based on democratic and professional procedures (Kohlberg, 1973). The topic was raised in the interview with the pilot Jarle Gimmestad. His general stance is to assume that one should do things by the book, since the rules and procedures have been designed under more or less ideal conditions, by people who are competent and well informed. "When you are in a heated situation, with limited access to information and pressure to make a quick decision, you can assume that the outlined rules have been established by calm heads, who have had time to consider the ramifications of the various alternatives" (Gimmestad, 2016). Kohlberg ranks the social contract reasoning below that of the principled, universal one, but that in itself does not suffice to say that a decision based on the latter is better than one based on the former.

True to their prescriptive stance, the leaders at Søbakken decided to create a barbecue for the residents. In an email, Helén Norlin explained: "One of our aims at the nursing home was to create "the good life" for the residents, and we could put many of our ideas and projects under that motto. "The good life" also has to do with trusting people in the local community and their wish to contribute to the wellbeing of those living at Søbakken. That included the fisher. We had complete trust in him when he said that the fish was fresh from the sea and of the best quality. Many at the nursing home were personally acquainted with him, and knew that he had the best intentions and was reliable" (Norlin, 2016). 
The leaders called in extra volunteers to analyze each piece of fish carefully before it was put on a plate and served to a resident, to minimize the risk of harm. The barbecue was a great success, causing jubilation among the residents. The air was filled with the smells of a good life by the sea, and nobody got hurt in any way. The leaders avoided repercussions for breaking the law and taking the risk.

The author has presented the grill party dilemma to professionals and managers in healthcare and in HSE functions on a number of occasions, and asked them to take a stand. It has been interesting to observe how the case evokes different moral intuitions about whether it is acceptable to go ahead and serve the fish, or not. A majority tends to say yes to the grill party, while a vocal minority says they would turn down that offer, based on a respect for legislation, and in the name of food safety. One leader from a local council, when presented with the case, said he would have taken immediate steps to dismiss the leaders at Søbakken, had the incident happened in his organization. He did not accept the fact that the grill party created happiness and joy among the residents and employees as evidence that it was morally right and acceptable to initiate it. Instead, he was concerned about the lack of respect for legislation, and what could follow of further unlawful actions, once this one was deemed acceptable.

It is likely that the responses to the grill party would have been dramatically different if one or more of the residents had actually got a fishbone stuck in the throat or been harmed in some other way. People may applaud risk-taking when things go well, but if they go through some unfortunate circumstance they do not and somebody is injured, the judgement may be less positive, and even critical. The concept of moral luck highlights how actual outcomes affect moral evaluations of what people do and fail to do (Nagel, 1979; Williams, 1981). It was been widely discussed from a range of philosophical and practical perspectives (Biss, 2016; Hankins, 2016; Levy, 2016; Statman, 2015; Whittington, 2015). Moral luck appears to be an oxymoron, in that we are prone to think that the moral quality of what we do cannot depend on circumstances beyond our control. In reality, actual outcomes do affect our moral judgements, as Nagel notes. 
Whether we succeed or fail in what we try to do nearly always depends to some extent on factors beyond our control. This is true of murder, altruism, revolution, the sacrifice of certain interests over others - almost any morally important act. What has been done, and what is morally judged, is partly determined by external factors. However jewel-like the good will may be in its own right, there is a morally significant difference between rescuing someone from burning building and dropping him from a twelfth-storey window while trying to rescue him. Similarly, there is a morally significant difference between reckless driving and manslaughter. But whether a reckless driver hits a pedestrian depends on the presence of the pedestrian at the point where he recklessly passes the red light. (Nagel, 1979, p. 28)

The jewel-metaphor Nagel alludes to is from Kant's description of the good will, the motivation to act, which the German thinker considered as the only proper object of moral judgement, since it has full value in and of itself, independently of outcomes. In opposition to that view, Nagel draws attention to how external factors affect even the description of the act itself, of what a person has done. There is a morally significant difference, he argues, between a successful and an unsuccessful rescue attempt.

Similarly, we can say that there is a morally significant difference between creating a barbecue and a rich sensory experience of a good life for an elderly person, and giving him or her a final and painful meal. Theoretically, we may be convinced by Kant's argument regarding the good will, but once that moral reasoning exercise is over, fall back to a habit of giving moral weight to actual outcomes. There is a considerable tension between the general conviction that morality is unaffected by luck, and the particular moral judgements that are significantly influenced by how things happen to turn out. If a resident gets a bone in the throat and dies during the barbecue, it will affect the moral judgement of the decision to break the law and serve the fish.

Food was also at the core of smaller, everyday dilemmas at Søbakken, where the motivation to improve the quality of life for the residents came up against legal restrictions on what they could eat. One recurring issue was that residents would sometimes not be ready to eat at the specified times for serving hot food, because they were tired or asleep or indisposed 
in other ways. The solution could then be to reheat the food 2 or 3 hours later, when they were awake and hungry. However, the option to reheat food was illegal. From a legal point of view, that food should either be eaten in its current state of being cold, or thrown away. The restriction against reheating food is based on food safety and a concern for the health of the residents, and in many or most instances, it appears to be reasonable and make sense. At Søbakken, they decided to take a principled approach to each separate situation, and sometimes ended up making the evaluation that this particular instance of reheating food would not pose a health threat, and was morally acceptable. Sometimes they would put leftover potatoes in the fridge overnight, and fry and serve them the next day, instead of throwing what they saw as perfectly fine food (Norlin \& Borvik, 2016). Again, the responses to these small instances of civil disobedience and priority to personal, principled moral reasoning over Norwegian legislation, would have been seen in a completely different light if it had happened to cause harm to one or more residents.

\section{Moral Hazard and Moral Paralysis}

Attitudes towards moral luck from the decision-maker's perspective are likely to depend on the perception of personal cost. To what extent will I have to bear a personal burden if things go badly? In the moral risk literature, emphasis tends to be on the phenomenon of moral hazard, or on how people who feel protected against negative costs of their actions, tend to take higher risk than they otherwise would have done, due to the perception that they will not have to bear the burden if things go wrong. Moral hazard occurs when an insurance customer takes a higher risk with his or her properties, based on the knowledge that if things go wrong, the insurance company will pay the cost (Aron-Dine, Einav, Finkelstein, \& Cullen, 2015; Parsons, 2003; Sealey, Gandar, \& Mazumdar, 2016). In the classical sense, moral hazard in insurance refers to " $(\mathrm{t})$ he possibility that the policyholder, knowing that he is insured, will change his behavior in a way that produces undesirable outcomes: in particular, he may become more careless" (Parsons, 2003, p. 448). More generally, a person insulated from risk, may become careless and 
engage in more risk taking than he would have done if he had been fully exposed to risk. He or she is less careful, since the cost of any mishaps for the most part will be taken care of by other parties. Most insurance companies are keenly aware of the dangers of moral hazard, and are therefore wary of offering conditions where the customers only have to take an insignificant part of the burden in case of an accident.

Moral hazard also occurs when banks and other financial institutions engage in reckless transactions and investments, on the assumption that the authorities will save them if the market collapses. In work settings, the highest ranked professionals in an organization can engage in harassment and other anti-social behavior, expecting that their expertise and status as being irreplaceable experts will protect them against sanctions. Under such conditions, the agents do not fear moral luck, because they perceive themselves as invulnerable. For this reason, they may not hesitate to engage in an activity that may turn out to go horribly wrong. More specifically, moral hazard occurs in health care settings where the moral risks in relation to different treatments are measured (Antommaria \& King, 2016; Brunnquell \& Michaelson, 2016).

The distinction between active and passive mistakes is useful in identifying the behavioral consequences of moral hazard. Human beings make mistakes of both kinds, but under a moral hazard regime, it is more likely that active mistakes dominate. The decision-maker worries less about the personal consequences, and takes more risk than if he or she would have had to take the burden of failure. From the decisionmaker's perspective, moral hazard neutralizes the threat of bad moral luck: It may exist, but that is not a worry for a person who experiences protection against punishment or other forms of negative consequences for having caused bad outcomes.

Another important and somehow neglected phenomenon in decision-making and moral risk is on the other side of the perceived protection spectrum from moral hazard. A decision-maker who feels fully exposed to repercussion in the event of a bad outcome, even when the risk he or she have taken appears to have been reasonable, will tend to act in an overtly cautious manner, and avoid doing anything that might conceivably end up badly. Fear of bad moral luck can lead to what we may call moral paralysis, a passive and cautious 
pattern of conduct. The decision-maker expects blame and criticism, even if the unfortunate unfolding of events has been highly unexpected, and strongly influenced by unforeseeable circumstances. If things go wrong, they expect to be alone in having to take the moral burden, with limited or no support from the organization or network to which they belong. With moral paralysis, a decision-maker will tend to avoid what could turn out to be active mistakes, and thus end up making passive mistakes instead.

In school settings, moral paralysis can lead teachers to keep children indoors to avoid responsibility for harmful consequences of risky play in the schoolyard. A report from the Association of Teachers and Lecturers in the United Kingdom documents widespread bans on traditional children's games in schools, and prohibitions against letting pupils play outside in the snow in winter, out of fear that they might slip and hurt themselves (ATL, 2011). The report connects a sharp decline in field trips outside the schools to the demand for detailed risk assessments of the situations that might occur during such trips. It has created a reluctance amongst teachers to take personal responsibility for harm to the pupils, no matter how unexpected and improbable. As noted in chapter one, risky play in childhood can have a crucial anti-phobic effect, in that it allows children to gain experiences in dealing with dangerous situations (Sandseter \& Kennair, 2011). Moral paralysis amongst preschool and school teachers, then, can have the negative effect of barring children from engaging in healthy anti-phobic activities. Avoiding the active mistake of allowing children be involved in play that actually harms them, takes precedence over avoiding the passive mistake of isolating children from potentially important learning experiences.

Moral luck is a worry for a decision-maker operating under moral paralysis, because he or she will personally have to bear the burden of actual negative outcomes. It calls for cautious decision-making and behavior, a risk-averse attitude geared towards not being involved in any kind of activity that might conceivably harm anyone, the moral equivalent of strict liability in law.

Moral reasoning and decision-making in organizations need to find a path between the polarities of moral hazard and moral paralysis, a golden mean between excessive and stifled moral risk-taking among professionals. 
Applied to a nursing home context, we can imagine that the decision-makers face one hundred situations where they have the opportunity to enrich the lives of the residents by exposing them to risk of harm. Under moral hazard conditions, they do not have personal incentives to be cautious, and can thus end up choosing the risky option every time, while under moral paralysis conditions, they will have to bear the personal burden in case of an accident, and may therefore reject the risky option every time. The middle ground is one where leaders and employees at a nursing home will sometimes take chances and involve the residents in activities that are at once enriching and potentially harmful, and at other times say no to these options.

\section{$4 \quad$ Supportive Leadership}

The two leaders at Søbakken started a range of activities with the residents at the nursing home, in order to meet their desire to come closer to life, and some of them involved a raised risk of harm. In taking these decisions and initiatives, they had the support of their own leader in the local council. She was a person they would call in moments of doubt, in order to get clearance for going ahead with a risky plan. The narratives from Søbakken indicate that the decision-making and activities took place in the middle ground between moral hazard and moral paralysis, that is, between the extremes of being fully insulated against negative consequences of one's own actions, and of being alone in bearing the cost of any unwelcome outcome of one's decisions. The resolve of the local council leader to stand by the leaders at Søbakken in case of an accident or misadventure was never put to the test, because such situations never happened. To some extent, that leader may have had good moral luck in the circumstances she faced. Nagel describes this category of moral luck as follows:

The things we are called upon to do, the moral tests we face, are importantly determined by factors beyond our control. It may be true of someone that in a dangerous situation he would have behaved in a cowardly or heroic fashion, but if the situation never arises, he will never have the 
chance to distinguish or disgrace himself in this way, and his moral record will be different. ... (O)ne is morally at the mercy of fate, and it may seem irrational on reflection, but our ordinary moral judgements would be unrecognizable without it. We judge people for what they actually do or fail to do, not just for what they would have done if circumstances had been different. (Nagel, 1979, pp. 33-34)

Along this line of thinking, the council leader who supported the proscriptive activities and initiatives at Søbakken may have lived up to her word of standing by the decision-makers even in the face of an actual misadventure, or not. She never had the chance to distinguish or disgrace herself in this manner, and so may either have had bad or good circumstantial moral luck in that regard.

Other leaders have had their abilities to stand by their subordinates tested and exposed. In 2007, two ambulance workers in Oslo experienced a lack of leadership support in the aftermath of an incident where they mistakenly thought a person did not need to be taken to the hospital (Schjenken, 2008; Østli, 2008, 2009). During a dramatic encounter in a crowded park in Oslo, one person had been knocked down, and was bleeding from a head wound. The ambulance personnel checked him to find out if he would need further treatment at the hospital. They thought that he probably was on drugs, and decided to get him to his feet and take him to the hospital. Once on his feet, the man started to pee on the shoes and trousers of one of the ambulance people, and then went over to the ambulance and peed on that as well. Now the two professionals reconsidered their initial judgement, and thought the wounded man should be handed over to the police, who were also present. Surrounded by an angry crowd, the ambulance personnel decided to leave the park without the injured man. Later, it turned out that the wounded man had serious head injuries, and these most likely caused his aggressive behavior. He should have been taken immediately to hospital for treatment, and the delay in treatment probably worsened his condition (Østli, 2008).

The wounded man was dark skinned, and on the day after the incident, Kristin Halvorsen, the Finance Minister of Norway indicated that the ambulance personnel was racists. "Could this have happened 
to a white father of small children? Probably not.” (Magnus, 2007) The two ambulance workers received heavy criticism for racism, negligence, and bad professional work. In the beginning, the hospital leadership appeared to stand by them, but as the media storm increased in intensity, they decided to suspend the two, and start internal investigations. The top leaders at the hospital expressed concern for the reputation of the organization, and saw it fit to distance themselves from the two employees. The two ambulance workers were forbidden by their employer to make statements in the media about the incident, while the critical voices could be heard everywhere (Østli, 2008).

During the suspension, one of the ambulance workers quit his job, while the other decided to go public with his version of the story. $\mathrm{He}$ was a vastly experienced ambulance driver, with more than 100.000 previous assignments during 17 years, without negative remarks. Before the dramatic event in the park, he had just washed the ambulance clean of blood and urine from a previous incident, and he and his colleague had further assignments on the same day, after the park incident (Schjenken, 2008). Little did they know that their professional lives would be ruined because of a serious mistake in the park. The second ambulance worker also initially quit his job at the hospital, and later won a High Court case against one of the newspapers that labeled him a racist (Johansen, 2014).

Apparently, the ambulance personnel did not receive proper leadership support in the aftermath of the incident (Østli, 2008, 2009). They made a serious passive mistake, in not taking the injured man to the hospital, and had to take the total burden of the negative outcome on their own shoulders. The driver who has been most public about his experiences has talked openly about mental problems and thoughts of suicide. The top leadership at the hospital made it clear that they did not want to see him back in activities where he would have direct contact with patients, the kind of work he had excelled in previously (Østli, 2008). They questioned his ability to do the kind of work he found the most meaningful, helping and making a positive difference to other people. The hospital did have a psychological service for employees, but did not actively offer it in this case. It is very likely that the personal outcomes for the employees would have been vastly different if 
the leaders had stood up for them and offered support in the aftermath of the dramatic park incident (Østli, 2008).

Social workers are another group of professionals who face constant risks to their moral integrity, in that they have to make decisions that can negatively affect the lives of others. They, too, are vulnerable to bad moral luck (Hollis \& Howe, 1987). A child may be at possible risk from parents, and the social workers must decide whether to remove the child from its home. The distinction between active and passive mistakes is relevant here. During one year, the social workers may remove children that would actually have been remained unharmed by parents, an active mistake, and also decide not to remove children, who as it happens turns out to be harmed by parents, a passive mistake. The former kind of mistake cannot easily be documented, in the way the latter can. Ambulance workers encounter a similar challenge in balancing between intervention and help, and deciding that the persons in pain will manage well without professional assistance. Mistakes will occur in these circumstances. They are moral minefields, and the professionals who work under this kind of pressure to their morality deserve leadership support, even at the risk of weakened reputation. A leader, who prioritizes short-term reputational gain over long-term support for employees under pressure, is likely to lose internal credibility in the organization.

This chapter has explored the concept of moral risk, and the distinction between active and passive mistakes, primarily by using examples from the nursing home context of Søbakken. It has focused on three questions that have both theoretical and practical aspects: (1) To what extent do our moral evaluations of past decisions and behavior depend on actual outcomes? The concept of moral luck captures a paradoxical dimension of moral reasoning. On the one hand, we tend to assume that people should only be held responsible for aspects of their decisionmaking and conduct that are within their control. On the other hand, it seems to make a morally relevant difference whether we succeed or fail in our endeavors to help or support other people. We have seen that omission bias is the tendency to judge harm caused by action to be more serious than the similar harm that comes about through omission or inaction. The Søbakken activities enriched the residents' lives in multiple 
ways, but also in some cases increased the likelihood of harm. The leaders at the nursing home generated a shift from a proscriptive ethics, accentuating the negative duty of not hurting others, to a prescriptive ethics, answering to the positive duty of creating wellbeing and a good life. That move made it relevant to pose the question of (2) what kind of protection against sanctions should be in place for people who take risky decisions at work. The suggestion in this chapter has been that there is a need to find a middle ground between moral hazard, where people feel insulated against taking the burden if things should end badly, and moral paralysis, where people become passive because they feel that they will have to take the burden alone if things should end badly. Moral hazard can lead to an overload of active mistakes, while moral paralysis can encourage passive mistakes. Leaders are the prime initiators of practices to handle moral risk. Thus, the latter part of the chapter has addressed (3) what the role of leaders is in cases where either active or passive mistakes from employees lead to bad outcomes. These are the situations where the leaders' ability to stand by their subordinates comes to the test, and where some fail, while others truly excel.

\section{References}

Antommaria, A. H. M., \& King, R. (2016). Moral hazard and transparency in pediatrics: A different problem requiring a different solution.

Aron-Dine, A., Einav, L., Finkelstein, A., \& Cullen, M. (2015). Moral hazard in health insurance: Do dynamic incentives matter? Review of Economics and Statistics, 97(4), 725-741.

Asch, D. A., Baron, J., Hershey, J. C., Kunreuther, H., Meszaros, J., Ritov, I., et al. (1994). Omission bias and pertussis vaccination. Medical Decision Making, 14(2), 118-123.

ATL. (2011). The Association of Teachers and Lecturers: Over-zelous schools ban British bulldag and conkers. Retrieved from https:/www.atl.org.uk/ Images/18\%20April\%202011\%20-\%20Over-zealous\%20schools\%20 ban $\% 20$ British $\% 20$ bulldog\%20and\%20conkers\%20-\%20ATL.pdf.

Bangerter, L. R., Heid, A. R., Abbott, K., \& Van Haitsma, K. (2016). Honoring the everyday preferences of nursing home residents: Perceived choice and satisfaction with care. The Gerontologist, gnv697. 
Baron, J., \& Ritov, I. (2004). Omission bias, individual differences, and normality. Organizational Behavior and Human Decision Processes, 94(2), 74-85. Biss, M. (2016). Radical moral imagination and moral luck. Metaphilosophy, 47(4-5), 558-570.

Brunnquell, D., \& Michaelson, C. M. (2016). Moral hazard in pediatrics. The American Journal of Bioethics, 16(7), 29-38.

Carlsen, A., \& Kvalnes, Ø. (2015). Lightness of radical change: On the positive transformation of a nursing home. Paper presented at the Academy of Management, Vancouver.

Carnes, N., \& Janoff-Bulman, R. (2012). Harm, help, and the nature of (im) moral (in) action. Psychological Inquiry, 23(2), 137-142.

Gimmestad, J. (2016, 18th November). Interviewer: Ø. Kvalnes.

Hankins, K. (2016). Adam Smith's intriguing solution to the problem of moral luck. Ethics, 126(3), 711-746.

Hollis, M., \& Howe, D. (1987). Moral risks in social work. Journal of Applied Philosophy, 4(2), 123-133.

Johansen, G. S. (2014). Erik Schjenken vant i Høyesterett. Journalisten.

Kohlberg, L. (1973). Collected papers on moral development and moral education. Harvard University, Center for Moral Education.

Levy, N. (2016). Dissolving the puzzle of resultant moral luck. Review of Philosophy and Psychology, 7(1), 127-139.

Magnus, G. (2007, 10th August). Ville neppe hendt hvit småbarnsfar. Aftenposten.

Nagel, T. (1979). Moral luck mortal questions. Cambridge: Cambridge University Press.

Norlin, H. (2016, 10th August). Interviewer: Ø. Kvalnes. e-mail correspondence.

Norlin, H., \& Borvik, K. (2015, 15th August). [Reflection note].

Norlin, H., \& Borvik, K. (2016, 28th November). Interviewer: Ø. Kvalnes.

Paque, K., Goossens, K., Elseviers, M., Van Bogaert, P., \& Dilles, T. (2016). Autonomy and social functioning of recently admitted nursing home residents. Aging \& Mental Health, 1-7.

Parsons, C. (2003). Moral hazard in liability insurance. The Geneva Papers on Risk and Insurance Issues and Practice, 28(3), 448-471.

Ritov, I., \& Baron, J. (1990). Reluctance to vaccinate: Omission bias and ambiguity. Journal of Behavioral Decision Making, 3(4), 263-277.

Sandseter, E. B. H., \& Kennair, L. E. O. (2011). Children's risky play from an evolutionary perspective: The anti-phobic effects of thrilling experiences. Evolutionary Psychology, 9(2), 257-284. 
Schjenken, E. (2008, 8th April). Hva som skjedde i Sofienbergparken. Aftenposten.

Sealey, C. W., Gandar, J. M., \& Mazumdar, S. C. (2016). Guaranty funds and moral hazard in the insurance industry: A theoretical perspective. International Trade and International Finance (pp. 527-545). Springer.

Spranca, M., Minsk, E., \& Baron, J. (1991). Omission and commission in judgment and choice. Journal of Experimental Social Psychology, 27(1), 76-105.

Statman, D. (2015). Moral luck and the problem of the innocent attacker. Ratio, 28(1), 97-111.

Whittington, L. J. (2015). Getting moral luck right. The philosophy of luck, (pp. 205-218). John Wiley \& Sons, Inc.

Williams, B. (1981). Moral luck: Philosophical papers 1973-1980. Cambridge: Cambridge University Press.

Østli, K. S. (2008). En stemplet mann Aftenposten/A-Magasinet.

Østli, K. S. (2009). Ambulansesaken/Ali Farah-saken. Oslo.

Open Access This chapter is licensed under the terms of the Creative Commons Attribution 4.0 International License (http://creativecommons. org/licenses/by/4.0/), which permits use, sharing, adaptation, distribution and reproduction in any medium or format, as long as you give appropriate credit to the original author(s) and the source, provide a link to the Creative Commons license and indicate if changes were made.

The images or other third party material in this chapter are included in the chapter's Creative Commons license, unless indicated otherwise in a credit line to the material. If material is not included in the chapter's Creative Commons license and your intended use is not permitted by statutory regulation or exceeds the permitted use, you will need to obtain permission directly from the copyright holder.

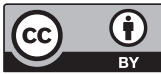

